\title{
Educational Micropolitics and Distributed Leadership
}

\author{
Joseph Flessa \\ Ontario Institute for Studies in Education, University of Toronto
}

\begin{abstract}
This article critically reviews two bodies of literature that potentially share common concerns, yet rarely overlap: distributed leadership and educational micropolitics. Alternative explanations for the split between these two analytical approaches to school organization are explored in sections on problem framing, methodology, and the marketplace of educational research and publishing. The article concludes that the separation between explorations of educational micropolitics and distributed leadership is both consequence and reflection of an increasingly prevalent managerialism required in the current policy context, which emphasizes smoothing out micropolitical conflict rather than examining it or learning from it.
\end{abstract}

The study of educational politics foregrounds disagreement. Researchers identify the ways that various stakeholders offer competing claims on scarce resources and attempt to influence policy formation and implementation at different times and at various levels of governance. Examinations of educational politics focus attention on our contradictory aspirations for schools as well as disagreements about the means to achieve the goals that are set for them. Understanding educational politics requires examining how, why, and with what result conflicts emerge. As Iannaccone (1991) put it, "A politics perspective's unique focus is on processes for producing policy from conflict" (p. 467).

The articles in this collection demonstrate that the scholarship on educational politics encompasses a wide range of levels of analysis: Some work examines federal policymaking and implementation; other articles look at the intersection of municipal governance and local school district administration. The focus of this article is within-school politics, a large area of study which overlaps with the literature on school change and reform or, as Mawhinney (1999) put it, "the problems arising when macro directions meet micro realities" (p. 159). The study of politics within the school—micropolitics—is sometimes understood as the study of how things really work, not how an organizational chart or a principal's action plan would like them to work. Marshall and Scribner (1991) identified power relationships, conflict, and the policy process as concepts central to the study of political dynamics that exist within schools (p. 349). According to

I appreciate the close read that the issue editors and two anonymous reviewers gave to an earlier version of this article. Thank you also to Amy Ryken of the University of Puget Sound, Roland Coloma, Indigo Esmonde, Ruben Gaztambide-Fernandez, and Lance McCready of OISE/UT for discussions that improved my argument.

Correspondence should be sent to Joseph Flessa, Educational Administration, Department of Theory and Policy Studies, Ontario Institute for Studies in Education of the University of Toronto, 252 Bloor Street West, Toronto, Ontario M5S 1V6, Canada. E-mail: jflessa@oise.utoronto.ca 
Hoyle (1982) micropolitics "is characterized more by coalitions than by departments, by strategies rather than by enacted rules, by influence rather than by power, and by knowledge rather than by status" (p. 88).

The study of educational leadership at the school site would seem to provide a rich opportunity to examine conflict and to explore the ways that ideals and realities or plans and implementation diverge: Teachers and administrators do not always share a vision of schooling or work collaboratively; educators and parents are often mutually suspicious and sometimes antagonistic; school site reform plans shift and change over time because of the specific people involved. The study of school level educational leadership through the lens of micropolitics has the potential to generate interesting and potentially useful analyses of the different experiences and expectations of those closest to educational policy implementation.

Nevertheless, research into distributed leadership, a significant and mostly new body of educational research, has been much more likely to avoid micropolitical analyses than to conduct them. The distance between micropolitics and educational leadership can be illustrated in this shorthand way: Two collections of work that both reflect and examine the growing significance among educational leadership researchers of "distributed leadership" have recently been published (Leithwood, Mascall, \& Strauss, 2009; Spillane \& Diamond, 2007). ${ }^{1}$ Both books provide a good foundation for understanding the empirical and normative claims being made in the name of distributed leadership; both include detailed case studies as well as broad diagnoses of the legitimacy of the new theoretical terrain being mapped. Although both books are concerned with the way that leadership is stretched across roles and positions, and both books include empirical investigation of the ways that leadership is enacted by different individuals at school sites, neither includes an index reference for "conflict" or for "politics"; micropolitics garners mention on 2 pages out of almost 500. Why does a literature that focuses on individuals' work within school sites and that investigates the different ways schools are managed and their implications fail to feature a micropolitical analysis?

In this article I attempt both to substantiate the claim that micropolitics and distributed leadership occupy surprisingly separate spaces in the literature on school leadership and to provide some ways of understanding it. I examine the distributed leadership literature and illustrate how it has addressed and avoided micropolitics. I also examine the micropolitics literature for potential points of connection. I then attempt to delineate the methodological, epistemological, and conceptual explanations for the divide between these two bodies of literature.

\section{AN OVERVIEW OF RECENT RESEARCH ON DISTRIBUTED LEADERSHIP}

It is not fair to review a body of literature solely to criticize it for what it isn't. It is fair, however, to ask why this body of work has grown and developed in the way that it has and to attempt to puzzle out why work with such popularity, empirical foundations, and conceptual versatility seems consistently to shy away from political questions. Politics is concerned with interests: In

\footnotetext{
${ }^{1}$ I am coauthor of a chapter in the Leithwood, Mascall, and Strauss collection. Consistent with a commitment to reflective practice, I am trying here to understand tensions and gaps that are present in my own work as well as in the work of others. Where I am critical of the field, I am also implicating myself and seeking to improve my own analyses.
} 
schools, where leadership is always distributed in some way, what happens when interests of different leaders, or of leaders and followers, don't converge? How are micropolitical alliances and coalitions mobilized to build consensus? Does the distributed leadership literature smooth out disagreements and assume uniformity? Does the literature perform a uniformity of interests, by neglecting the very topic? In this section, I review some of the recent literature on distributed leadership and examine the ways that micropolitical analyses are and are not utilized.

Distributed leadership is an increasingly popular concept associated with a growing body of empirical and normative writing in the field of education. Like many educational labels before it-“restructuring," for example_- "its conceptual elasticity is considerable" (Hartley, 2007, p. 202). One review of the literature summarized, "We found little agreement as to the meaning of the term "distributed leadership"' (Bennett, Wise, Woods, \& Harvey, 2003, p. 2). As two of the authors most closely associated with this work state,

The appeal of a distributed perspective lies partially in the ease with which it becomes many things to many people. Frequently used as a synonym for democratic leadership, shared leadership, collaborative leadership, and so on, the distributed perspective easily and effortlessly entered the discourse about school leadership and management. (Spillane \& Diamond, 2007, p. 1)

The flexibility of the concept explains some of its growing prevalence in discussions of school organization and administration. Another explanation derives from the fact that, in times of increasing accountability and the corresponding attention to leadership generally,

distributed leadership, ... it is argued, also enhances opportunities for the organization to benefit from the capacities of more of its members, permits members to capitalize on the range of their individual strengths, and develops among organizational members a fuller appreciation of interdependence and how one's behavior affects the organization as a whole. (Leithwood et al., 2009, p. 2)

In a policy environment that features "leadership" as a self-evident good, distributed leadership is even better. As the editors of a recent collection observe, "the overwhelming disposition of the contemporary, normatively oriented literature on distributed leadership is enthusiastic optimism about its anticipated benefits" (Leithwood et al., 2009, p. 2).

Distributed leadership is a popular concept with many overlapping definitions. So just what are some of these definitions around which most work seems to cohere? "Distributed leadership ... is group activity that works through and within relationships, rather than individual action" (Bennett et al., 2003, p. 3). A distributed perspective "is not a model but a conceptual lens or diagnostic tool for probing and analyzing practice" (Spillane, \& Diamond, 2007, p. 148). Building on the ideas of distributed cognition, distributed leadership describes the ways that leadership activities are stretched across different people and positions within organizations, and where the result is greater than the sum of the individual parts (Gronn, 2000, 2002; Spillane, 2006). It can be understood as an organizational, not individual, property (Ogawa \& Bossert, 1995) where leadership work "is done redundantly and sometimes jointly [and] it is hard to find any one person who is responsible for the accomplishment of change" (Heller \& Firestone, 1995, p. 84). Although the research literature remains agnostic about impact - "there are no empirical data on the effectiveness of distributed leadership, in terms of pupil or student achievement" (Bennett et al., 2003, p. 2) —and although there is striking scholarly agreement that studies of impact are needed to move the field 
beyond its current "adolescence" (Leithwood et al., 2009 p. 269) or "preadolescence" (Spillane \& Diamond, 2007, p. 163), some writing aimed at practitioners or reformers nevertheless asserts causality. For example, one work, The Distributed Leadership Toolbox, states in its preface, "Distributed leadership is a method for engaging educational practitioners in meaningful and timely dialogue about the effectiveness of their leadership practices as they relate to enhancing and changing classroom practices. This, in turn, enhances student learning" (McBeth, 2008, p. vii).

This conceptual tension runs throughout the literature, sometimes within the same work. Leadership is always distributed in some way within organizations, and consequently using a distributed framework is a descriptive task. "Distributed" leadership is also said to be something that schools should want more of and policymakers should promote. For example, The Distributed Leadership Toolbox includes both a CD and more than 50 pages of reproducible templates for school leaders' use yet begins its second chapter with a quote from Spillane: "Distributed leadership is not a blueprint for practicing school leadership more effectively" (Spillane, as cited in McBeth, 2008, p. 11).

Given the variety of ideas and purposes that fall under the label "distributed leadership," Mayrowetz (2008) concluded that "one universal usage of distributed leadership may never be achieved, and perhaps it is unadvisable to seek it given the proliferation of definitions that have emerged" (p. 433). He usefully identified four common uses of the term "distributed leadership," "which include the original descriptive theoretical lens and three prescriptions for how sharing leadership in schools can improve practice" (p. 424). They range from a "theoretical lens" (p. 425) to an antidote to the problems of school administration hierarchies (p. 438) and include greater "efficiency and effectiveness" (p. 429) and "distributed leadership as human capacity building" (p. 431). Given this diversity of approaches, I clarify my own use of terms here: In this article, the work I am drawing from utilizes the label "distributed leadership" differently, but I make claims about "the distributed leadership literature" in the singular. I do so not to suggest that this large and internally inconsistent body of work is uniform but because this is how the authors themselves have classified their work.

Research that explores "distributed leadership" often uses case study methodology where data collection strategies combine interviews and observations. Consistent with the norms of the field of educational administration, some distributed leadership studies rely on administrator self-reports or utilize larger scale survey research (e.g., Camburn, Rowan, \& Taylor, 2003). Other work combines both; one noteworthy mixed methods study utilized sampling logs for 52 school principals, collecting data on principals' work at random times throughout the day (Spillane, Camburn, \& Pareja, 2007). Causal or inferential claims about outcomes for students can not yet be substantiated rigorously and "the lack of serious effort ... to assess the contribution of greater leadership distribution to the long list of desirable outcomes typically invoked by advocates" is cause for "disappointment" (Leithwood et al., 2009, p. 280). Some researchers have called for methodological changes_-valid and reliable instruments and larger scale investigations — to build upon the current descriptive foundation (Spillane \& Diamond, 2007, p. 165).

Distributed leadership writing often includes built-in criticisms of the state of the current research. For example, in a study of Texas elementary schools, researchers "seeking implications for democratic school governance" (Maxcy \& Nguyen, 2006, p. 163), criticize existing distributed leadership frameworks for the elision of distributed leadership with "task delegation," neither 
of which is the same as "leadership enacted through democratic processes-processes engaging stakeholders in collective and deliberative determination of means, modes, and ends in schooling" (p. 164). This kind of critique asks researchers to pay greater attention to how, by whom, and to what ends leadership is distributed; such decisions are not ideologically neutral. Hatcher (2005) examined the relationship between the rhetoric of distributed leadership and the reality of managerial power. In her study of distributed leadership in a school improvement context in New Zealand, Timperley (2005) observed that there was a normative push in some of the literature for distribution of leadership activities without consideration of the quality of those activities. She concluded that this normative stance was more than naïve; it was also potentially negative. She wrote, "Distributing leadership over more people is a risky business and may result in the greater distribution of incompetence" (p. 417). Researchers investigating distributed leadership utilize multiple definitions of their terms and also debate the central concepts. Yet very little is said about school level micropolitics.

\section{The Absence of Micropolitical Analysis}

In work that asserts its central question is, "What does it mean to take $a$ distributed perspective?" (p. 2), Spillane and Diamond (2007) answered with virtually no explicit attention to politics, micropolitics, or conflict. The way their inquiry has been framed around "three broad categories: compass setting; human development; organizational development" (p. 3) circumvents what other scholars locate as central to studies of leadership, management, and professional community, namely, the way that goals, purposes, and strategies are contested (see, e.g., Blase, 1995; Blase \& Blase, 1997; Malen, 1995; Mawhinney, 1999).

Is the absence of specific mention of micropolitics simply a matter of using different vocabularies for studying the same thing, or have, in fact, scholars of distributed leadership neglected something so central as micropolitics? Spillane and Diamond (2007) stated that "in efforts to understand the practice of leading and managing schools, we must pay close attention to the interactions, not simply the actions" of individuals (p. 6). In other words, they acknowledge that the social processes at work involve give and take and that, by definition, leadership will involve not just the decisions of leaders but also those of followers, "because social influence is a two-way affair" (p. 9). However, when obvious links to the micropolitical work of leadership could be drawn, they are not. For example, they rely on Larry Cuban's (1988) leadership work to anchor their discussion of the overlap between management and leadership (Spillane \& Diamond, 2007, p. 153), but never mention the fact that the very citation they've used included three imperatives at the heart of leadership: instructional, managerial, and political. In another chapter in the Spillane and Diamond volume, Halverson (2007) demonstrated that he is aware that a focus on leadership distribution might overemphasize routines and structures and underemphasize the people who work with and within them. He concluded his chapter with a response to a rhetorical question:

Does reliance on the analysis of routines as the path to professional community give short shrift to the importance of interpersonal and spiritual leadership practice in schools? ... Routines merely establish the conditions for practice in organizations - the actual practices of teaching and learning involve levels of agency well beyond the determining structures of routines and tools. (pp. 57-58) 
There is little to disagree with in this conclusion: To say structures matter does not mean individuals do not. Nevertheless, this case study would only have strengthened its empirical contribution to our understanding of distributed leadership in practice by examining how routines and structures were established. By neglecting this conceptual realm, where micropolitics and leadership interact, the work may leave practitioners with the assumption that when conflict arises within their own setting, something is either wrong with them, their school leaders, or with their distribution of leadership. By leaving micropolitical conflict out of the leadership narrative, researchers may be encouraging leaders to consider their roles too narrowly, with potentially negative consequences. And as Bolman and Deal (2004) concluded, "Leaders fail when they take too narrow a view. Unless they can think flexibly about organizations and see them from multiple angles, they will be unable to deal with the full range of issues they inevitably encounter" (p. 433).

The Spillane and Diamond anthology does seek to debunk one of the "myths about distributed leadership," namely, that "distributed leadership is only about collaborative situations" (p.152). The editors argued that "a distributed perspective applies to situations where leaders have different or contrary goals as easily as it does to situations where leaders are striving for the same goal" (p. 152). In other words, the authors envision distributed leadership as a concept flexible enough to include conflict. Within their collection, Hallett (2007) described a school where a new principal, under intense pressure to raise test scores quickly, faced intense resistance from veteran staff. As Hallett explaind,

\footnotetext{
The teachers, the very people on whom [the principal's] success depended, were offended by her efforts to increase accountability. They refused to follow, and their own efforts to lead a movement against [the principal] resulted in an investigation of [the school]. The struggle to deal with all of these tensions was painful for everyone. (p. 102; see also Shipps \& White, 2009/this issue)
}

There are two relevant points to make here. First, this chapter's inclusion in a distributed leadership volume indicates that the editors are aware of the important role conflict can play in schools, and that a study of how leadership is distributed must sometimes include examination of conflict. Second, Hallett's chapter examines school micropolitics without using the language most familiar in the field. Although he examines coalitions, conflict of vision and goals, and fights for scarce resources, he does not utilize the vocabulary that, from a micropolitical perspective, would seem most to apply, concluding, "The leadership struggle at Costen Elementary teaches us that leadership is not inherent in organizational positions" (p. 102). This observation echoes examinations of the difference between authority and power, or between position and influence, found within some micropolitics writing, but it does not use those terms. Does this distinction matter?

It matters in the sense that the inclusion of micropolitics into both the conceptual and methodological underpinnings of their work would only seem to strengthen it, but it remains neglected even as an area of further research. For example, Spillane and Diamond (2007) concluded their volume with a call for the development of "valid and reliable ways to identify leadership and management practice" (p. 165), and yet the tools they evidently would like to see emerge do not appear to identify squarely the micropolitical processes that lie at the heart of the work of leadership. They acknowledged that after 9 years of field research for this project, 
leadership and management practice is not confined to structured and patterned time slots; it happens before and after school, on weekends, and during school hours both in formally designated routines such as grade-level meetings and during informal interactions over lunch or in exchanges snatched between classes. (p. 165)

But because their focus is solely on leadership and management, as if these were politically neutral processes, and because they do not foreground what constitutes leadership and management or what provides the setting for their enactment - the political realm - the instruments they call for seem to leave out a crucial piece of practice, which they have set as their goal.

Larry Cuban (1988) explained the political nature of teachers' and administrators' work in schools this way:

To the degree that teachers, for example, use their legitimate authority to allocate scarce resources to children, govern minors through a series of techniques, negotiate order, and bargain with members of the class, teachers act politically. Determining who gets what, when, and under what circumstances to achieve desirable ends - a classic formulation of political behavior-occurs in classrooms, schools, and districts. Although the settings differ for a kindergarten teacher and a high school principal, the core roles are the same. (p. xix)

A micropolitical lens need not be the only one utilized to shed light on school microprocesses. Not only is a descriptive analysis of how leadership is distributed by definition a study of "who gets what, when, and under what circumstances," but also the current educational environment emphasizes leadership as one of the best policy levers to pull to "achieve desirable ends." The lack of inclusion of a micropolitical perspective within the distributed leadership literature seems a missed opportunity both conceptually and strategically.

I make this critique cognizant of the fact that within some of my own published research there are missed opportunities for the examination of professional conflict and collegiality. In a study that focused on alternative approaches to formal leadership arrangements in schools (Grubb \& Flessa, 2006), we said little about micropolitics although potentially interesting insights could have been generated. Our research examined the ways that different schools had experimented with leadership arrangements alternative to the traditional principal/assistant principal hierarchy, and we uncovered a wide variety of alternative leadership approaches: dual principalships, coprincipalships, rotating principalships, and a school with no principal at all. Our purpose was to understand the trade-offs involved in pursuing the different models: What did they cost? Were they sustainable? Did stakeholders at the schools like them? We reached some general conclusions and highlighted particular sticking points at specific sites. But we did not write an article as fully attentive to the micropolitical processes at individual sites as we could have.

The largest micropolitical lesson learned in our research is that alternatives that diverge most from the principal/assistant principal model conflict most forcefully with the grammar of schooling (Tyack \& Cuban, 1995, p. 9). Such alternatives therefore require constant justification both inside and outside the school. All school community stakeholders-teachers, parents, community agencies, and students - have experience with more typical approaches. When leadership is distributed in ways that are in tension with taken-for-granted scripts of school administration, when the interpersonal and professional relationships of adults change, it would be quite surprising if no conflict resulted. 
Yet our study did not examine how micropolitical conflicts shifted and changed over time. Although the data were rich in their descriptions of the strengths and weaknesses of alternative approaches, we did not gather observational or longitudinal data that would enable us to describe the ways that stakeholders engaged micropolitics at different decision points. Our published work had more to say about policy implications of different alternative responses than it did about micropolitics between and among individuals.

\section{Distributed Leadership Research That Bridges the Two Perspectives}

There are a small number of examples of work that make explicit connections between the distributed leadership and micropolitics literatures. For example, Johnson's (2004) study from South Australia found that distributed leadership was itself a micropolitical strategy for implementing school reform projects. Calling it part of the " "positive politics' of negotiation, collaboration and conflict resolution to address issues of local concern in schools, rather than the "controlling politics' of new managerialism" (p. 267), Johnson observed that "school leaders candidly admitted using micropolitical strategies and tactics to select key staff to join these teams and to set the tone for their operation" (p. 274). Although not utilizing the term distributed leadership, West (1999) observed that "more democratic [organizational structures] tends to mean with rather more scope for micropolitical influences over directions and decisions" (p. 190). This observation led him to conclude that "it is important therefore that school leaders have deliberate strategies that they can draw on to try to minimize the micro-political influence of informal groups on school direction and policies" (p. 194). Although this conclusion reasserts a view of conflict and micropolitics as inherently negative and of leadership as its inherently positive counterbalance-conclusions that are potentially limiting-West has nevertheless pointed out some ways that school leadership and micropolitics are intertwined.

One recent example of research that stands out from the rest in its attempt to integrate distributed leadership and micropolitical perspectives is that of Storey (2004). Storey used case study data from England to deliver a critique of previous research in distributed leadership, taking as her starting point skepticism of the "mainly enthusiastic literature on leadership" (p. 249). Her article also succinctly lays out a handful of possible explanations for the popularity and prevalence of distributed leadership within the larger leadership discourse. For example, she argued that "the new emerging wisdom is that no single head or sole leader can handle the enormous complexity [of organizational leadership], hence the need for, and the attraction of, the concept of 'distributed leadership"' (p. 252). Storey also asked questions not commonly observed within this body of literature. For example, she sought to understand "what dynamics are unleashed when leadership is exerted at multiple points in a school organization?" (p. 254).

At the heart of Storey's analysis is a causal argument. Her analysis of case study data "reveals and explains how distributed leadership resulted in tension and conflicts between competing leaders" (p. 250), particularly between a department head and a school head. In other words, hers is a paper that seeks to show distributed leadership as cause, conflict as effect. Storey (2004) concluded that

the experiment in distributed leadership which is examined in this case surfaced fundamental tensions between competing leaders, namely the head teacher and significant others occupying positions as key 
subject leaders. These multiple leaders came increasingly into conflict as their competing visions, models and ideas of "success," "good practice," appropriate performance measurement at wholeschool, departmental, and individual levels, became increasingly evident. (p. 253)

Storey's study is partly a story of the pressures exerted on school leaders within an accountability environment that expects improvement quickly. It shows that conflicts arose around the content of leadership decisions, the appropriate realms for distributed decision-making, and the symbolic and substantive significance of different interpersonal approaches. As Storey (2004) put it, "Three issues emerged as critical: conflicting priorities, targets and time-frames; boundaries of responsibility; and competing leadership styles" (p. 257).

Storey's work is at least as much about the conflict between the rhetoric of distributed leadership and the lived realities of leadership delegation at the school site as it is about distributed leadership per se. Storey's explanation of the different leadership approaches of school head and the head of the science faculty, in the final analysis, relies less on the conceptual foundations of distributed leadership than it does upon a traditional, rational examination of how organizational incentives shape the approach that different policy actors take: "The different foci in this case were not primarily the result of different leadership styles or personality types . . . Rather, they reflected the differences in the pressures faced by these actors" (p. 262). Put another way (and borrowing phrasing from scholars of decision making), where school leaders stand on certain issues will depend on where in an organizational chart they sit.

With her exploration of the distribution of both leadership and conflict, Storey's work does something unusual, which is why it merited lengthy consideration here. Her work links the distributed leadership literature and the literature on educational micropolitics. Furthermore, her study, which presents a school's struggles, not a smooth story of inevitable one-directional development and progress, will likely be quite familiar to educators or others who would turn to the distributed leadership literature in a search for greater understanding of school change. Although work such as Storey's remains rare, it suggests the possibilities for developing both practical and theoretical insights latent in connecting these two strands of research.

\section{THE LITERATURE ON EDUCATIONAL MICROPOLITICS}

There are numerous studies that examine within-school politics, from a variety of perspectives. Scholars of this field note that although the amount of research in micropolitics has, naturally, grown over time, the field's "conceptual boundaries and distinctive features remain elusive and contested" (Malen \& Cochran, 2008, p. 148). Some studies examine the ways that leadership approaches or strategies encourage teachers' empowerment (see Blase \& Blase, 1997). Other studies examine the ways in which the implementation of new governance structures has an impact on teachers' sense of collective responsibility or positive school culture (Bryk, Sebring, Kerbow, Rollow, \& Easton, 1998; Lee \& Smith, 2001). Some works explore the ways that race (McKenzie $\&$ Scheurich, 2004) and gender (Datnow, 2001) shape professional relationships among educators and between educators and students. There is no lack of articles that set out to make a point similar to one embedded within this paper, namely, that leadership and administration literatures neglect micropolitics (see especially Malen, 1995; Mawhinney, 1999). Others have made the point that more attention to micropolitics might assist practicing administrators more than the normative 
idealized theorizing that, in a caricature, represents leadership and administration writing. What does the field stand to gain or lose in this way of framing a conversation about leadership? The purpose of this section is to highlight research in educational micropolitics that includes research questions or findings that potentially could connect to research in distributed leadership.

Blase and Blase (1997) disagreed with a conceptualization of school micropolitics that emphasizes conflict to the exclusion of consensus. In work that examines the micropolitical strategies school leaders use to achieve school goals, they assert that "micro-politics deals with the realm of cooperative (i.e., collaborative, collegial, consensual, democratic) as well as conflictive forms of interaction in organizational settings" (p. 138). In their work they seek to complicate the fact that "historically, the study of micropolitics has focused on conflictive, negative, and dysfunctional relations between and among individuals and groups in organizational settings" (p. 160).

In a comprehensive review of the micropolitics literature, Malen (1995) concluded that "the politics of schools has received more attention than the politics in schools" (p. 148). She finishes her review with both methodological and theoretical recommendations for the field.

While there are exceptions, the tendency for processes to maintain familiar power configurations is pronounced. Our capacity to account for these dynamics is constrained by the lack of longitudinal and comparative data.... More robust designs that probe actor relations, the conditions that produce, perpetuate, or precipitate shifts in patterns of politics and the consequences of these styles of play for the distribution valued outcomes would bolster our ability to interpret the politics in schools. (p. 160)

What is interesting about these recommendations is that distributed leadership research seems to have taken up one of Malen's calls for action but not the other. Inarguably, distributed leadership research has sought to examine the ways that leadership is enacted outside "formal decision areas" and "familiar power configurations." At the same time, it would be difficult to identify a consistent line of research within the field of distributed leadership that has attended to "shifts in patterns of politics" over time.

The literature on teachers' work also provides some insight regarding the ways that school micropolitics and school leadership are intertwined. Some of this work examines the meaning and purpose of conflict. For example, in her case studies of middle schools, Achinstein (2002) concluded that

conflicts give teachers the opportunity to look at schools as they are and decide what they can become. Conflict, it turns out, offers a context for inquiry, organizational learning, and change. As colleagues air differences, build understanding across perspectives, and seek changes enhanced by divergent thinking, conflict becomes constructive for the community and school. (pp. 2-3)

Much of the literature on micropolitics views micropolitical conflicts within schools as pathologies to be healed or obstacles to be overcome. Mawhinney (1999) summarized this perspective by stating that micropolitics "swirl in and around schools, often constraining the systemic efforts at changes" (p. 160) and that "members of the school community must find ways of resolving conflict which ensure that decisions made command enough respect that they are widely accepted" (p. 160). Although likely not its intention, this way of characterizing politics suggests not only that it is fundamentally obstructionist but also that it is possible within schools to arrive at a time and place where politics and conflict are not present. Because the leadership literature 
often takes as its starting point a normative notion that "leadership" is about progress- "We refer to leadership as change-related functions such as setting a vision and goals for the school and motivating stakeholders to move towards their achievement"-and because micropolitics is commonly viewed as that which gets in the way of progress, it is not surprising that the literatures would not overlap, even though the experiences of leadership and politics in schools do (Heck \& Hallinger, 2005, p. 240, note 2).

Although not described as an examination of "distributed leadership," Coburn's 2006 article does focus on what she calls "authority relations" and "the micro-processes of problem framing during implementation" (p. 347). Coburn identified a variety of gaps in the literature on policy implementation that have significance for the study of school leadership. For example, she noted that policy studies often examine how leaders' understandings and interpretations of policy have an impact on implementation. "But this line of work has not addressed questions of problem framing and, as such, has tended to ignore this crucial aspect of the policy implementation process" (p. 344). There are parallels in Coburn's assessment of the literature to some of the critiques of the leadership literature, namely, that rarely do advocates of new or better "leadership" fully articulate an answer to the question of leadership: For what? Or to what end?

The strength of Coburn's article may provide one answer to why there is relatively little examination of micropolitics within the distributed leadership literature. She relied on ethnographic methods and in-depth analysis of one school. This approach enabled her to observe micropolitical orientations and negotiations over time, and her article contains many chronological descriptors, for example, noting when previously nascent issued "bubbled up" (p. 353). Evidence of when, how, and with what results different micropolitical processes emerged was possible because of the single-case nature of the research design; a multicase study would have necessarily sacrificed this degree of detail. With such rich data, Coburn is able to pay "special attention to the role of authority in the interactive process of making meaning in schools" (p. 348). By studying the give and take between and among school community members as instructional reforms are attempted, she highlights the way that conflicts and micropolitics shift and change over time. Snapshots and interview studies are unlikely to produce similar data sets.

Coburn's conclusions should resonate with scholars of leadership for a variety of reasons. Neither simply a study of policy implementation nor of teachers' professional community, her work "provided evidence that all voices are not equal in the social negotiation of meaning. Rather, the way in which individuals jointly construct their understandings of policy is shaped by and in turn shapes authority relations" (p. 373). Coburn's study of micropolitics revealed not only that authority and resources-leadership_-are distributed within schools, but also why and how. An examination of leadership without an examination of the politics of issue framing would have been unlikely to generate this deeper understanding of policy implementation.

\section{EXPLAINING THE DISTANCE BETWEEN THE TWO AREAS OF STUDY}

In an attempt to understand how two bodies of literature with common interests have developed in ways that are more divergent than convergent, I turn to three potential explanations. In the three sections that follow I propose that part of the explanation derives from the fact that at their core, the research problems are framed differently, that the research questions are pursued differently, 
TABLE 1

Comparison of Distributed Leadership and Micropolitics Research in Education

\begin{tabular}{|c|c|c|}
\hline & Distributed Leadership & Micropolitics \\
\hline $\begin{array}{l}\text { Typical narrative that } \\
\text { frames the literature }\end{array}$ & $\begin{array}{l}\text { Distribution of influence among leaders } \\
\text { shapes school culture and outcomes } \\
\text { Emphasis in normative literature on } \\
\text { progress and solutions }\end{array}$ & $\begin{array}{l}\text { Schools are shaped through dispute } \\
\text { Emphasis on conflict and problems }\end{array}$ \\
\hline $\begin{array}{l}\text { Typical methodological } \\
\text { approach }\end{array}$ & $\begin{array}{l}\text { Surveys (self-reports) of administrators } \\
\text { and other school leaders. Potentially } \\
\text { large scale. } \\
\text { Case studies relying upon observations } \\
\text { of public meetings and interviews with } \\
\text { key subjects }\end{array}$ & $\begin{array}{l}\text { In-depth qualitative methods including } \\
\text { ethnography. Particular and small } \\
\text { scale. } \\
\text { Case studies relying upon observations } \\
\text { of public meetings and interviews with } \\
\text { key subjects }\end{array}$ \\
\hline $\begin{array}{l}\text { Marketplace for this } \\
\text { research }\end{array}$ & $\begin{array}{l}\text { School leaders and policymakers } \\
\text { Researchers }\end{array}$ & Researchers \\
\hline
\end{tabular}

and that the marketplace for educational research creates more attractive incentives for separate than interdisciplinary inquiry because researchers are rewarded for differentiation (see Table 1).

\section{Problem Framing}

Part of the explanation for the distance between these two potentially convergent bodies of literature is found in how the research phenomena themselves are framed. Methodological and conceptual decisions define those aspects of school life considered pertinent and significant and those which are not. One explanation for the distance between micropolitics and distributed leadership research is that although potentially compatible bodies of work, the issues that they consider and the questions they pursue have been constructed separately.

Many observers of policy and politics describe and analyze the ways that issue framing influences decision making. For example, Cuban (2001) used the words "framing" and "defining" interchangeably (p. 4) when discussing how to solve problems and manage dilemmas. Frame analysis represents its own methodological approach to understanding policy issues. Anderson and Rodway (2008); Coburn (2006); and Creed, Langstraat, and Scully (2002) provided overviews of this approach and demonstrated how it can be brought to bear on particular issues. Bolman and Deal (2004) offered one of the most accessible overviews of how to use different conceptual frames to understand managerial and leadership issues within organizations; their work is influential in educational leadership circles because it is frequently taught in educational administrator preparation and development programs. Bolman and Deal articulated four alternatives - the structural frame, the human resource frame, the political frame, and the symbolic frame-and suggested that although some issues may be best understood from only one frame, leadership requires agility in using all four lenses. The distributed leadership literature's attention to decision making roles and responsibilities and the impact on a school's sense of collective endeavor would suggest that it views organizations fundamentally from the structural and human resource frames; this emphasis may lead it to underemphasize inquiry into both the political and symbolic substance of leadership. 
Perhaps the best known writing on the framing of national political issues comes from cognitive linguist George Lakoff $(2004,2006)$. His work emphasizes that framing political issues is more than simply spinning them with different shorthand; framing is the structural way that different moral and conceptual priorities are articulated and the way that momentum is organized to achieve them. Although his work examines macrolevel political framing, there are lessons for the topic under consideration in this article. Micropolitics and leadership distribution are framed within the research and professional literatures as occupying entirely different realms of inquiry and, it seems, different sets of skills and interests. To study the work of leadership and micropolitical skill so separately seems to make a larger point about how we conceptualize both. Is this framing implicitly suggesting that leadership is best understood by studying it unmuddied by politics and that micropolitics make leadership less important?

Although Deborah Stone (2002) examined political decision making and not educational micropolitics or educational leadership per se, her conclusions about the ways that policy arguments are framed also have implications for how within our fields of research we choose to organize our own knowledge. She said, "Whether they are conceptual, physical, or political, boundaries are border wars waiting to happen. At every boundary, there is a dilemma of classification: who or what belongs on each side?" (p. 382). By deciding to include management in their theorizing about distributed leadership but not politics, Spillane and Diamond (2007), for example, classified politics as outside the realm of investigation. That these boundaries are created and re-created rather than natural or inherent seems clear from an examination of the literature. Less clear is what purposes are served by these distinctions. Perhaps, as Stone suggested, this categorization is evidence of an argument of what matters most. She said, "Policy argument takes the general form of claiming that something should be included in or excluded from a category" (Stone, 2002, p. 380).

Ogawa (2005) argued that "different conceptions of organizations should produce correspondingly different conceptions of leadership" (p. 93). It would follow that a conception of distributed leadership that incorporated the micropolitical realities of the school would have at its heart a conception of the organization as a place where outcomes are largely the result of individuals and coalitions pursuing their own interests, resulting in fights over real and symbolic resources, in a school's goals and vision as well as its curriculum, schedule, and markers of status. The fact that most of the distributed leadership research does not include a micropolitics dimension implies that the underlying conception of schools as organizations is one where dynamics other than micropolitics are most central. It is possible that a rational, potentially closed systems perspective (see Scott, 1987) informs distributed leadership research, where organizations are understood primarily as technical, managerial domains.

\section{Methodology}

Another explanation for the distance between distributed leadership and micropolitics research may be found in the different methodological demands in each area of study. As mentioned earlier, micropolitics studies tend to be extensive, expensive, small-scale ethnographic investigations whereas some of the distributed leadership literature pursues larger samples of schools.

Sample size aside, methods questions are suggestive in other ways. For example, establishing the contribution that her research regarding gender politics makes to the literature on school change, Datnow (2001) observed that "what are common to definitions of micro-politics are the 
elements of subversiveness and seediness. It is therefore not surprising that most studies of school change do not address micro-politics, particularly because of the research relationships and ethics that might be placed at risk by it" (p. 132). Concluding that "as educators and researchers we need to learn more about how teachers with competing interests and ideologies gain consensus on the means and the substance of school change" (p. 151), Datnow advocates for school-based inquiry that examines politics more explicitly. Similarly, Malen and Cochran (2008) asserted that

given the prevalence of more covert and murky manifestations of power, scholars who focus on the micro-politics of schools may have to make comparable investments [a great deal of time at the site of study] to display, more explicitly and systematically, how all the faces of power might be manifest in schools. (p. 169)

These recommendations are consistent with the arguments made in this review. What remains unclear is just how likely such research is to occur in a research policy environment that some critics argue is increasingly working at cross purposes to good ethnographic practice (see Haggerty, 2004; van den Hoonaard, 2003, for critique of research ethics review boards).

From an historical perspective, the methodological approaches that separate distributed leadership and micropolitics may be traceable to the Progressive Era impulse to take politics from schooling and to professionalize and rationalize school management (Tyack \& Hansot, 1982). School site leadership issues have commonly been examined as technical and managerial issues with methodological approaches borrowed from administrative science.

\section{The Marketplace for Educational Research}

Economists explain the state of education research by examining its market; they are concerned with how the realities of supply and demand create incentives that make certain kinds of research production more likely than others. Goldhaber and Brewer (2008) found that "the market for education research may not function efficiently, in the sense that not enough of the research that is needed gets done and too much of what is not needed is produced" (p. 201). They argued that within universities, departmental autonomy (they use the word "silos") and the correspondingly separate incentive systems codify boundaries between different areas of research. Subsequently,

there is often relatively little interaction and collaboration across these boundaries. This autonomy has important implications; for example, it reinforces the production of work based on one disciplinarybased view of the world, and it minimizes the sharing of methods and new developments and institution-level scrutiny of the quality of research. (p. 207)

Furthermore, they concluded, "it is not uncommon for researchers in one discipline studying a particular issue to totally ignore a robust literature on that issue outside their discipline" (p. 210).

Although Goldhaber and Brewer's diagnoses are compelling, they do not perfectly match the case of educational micropolitics and distributed leadership. Departments of educational administration house many of the scholars who have written works cited previously; this silo includes the surprisingly separate domains of micropolitics and leadership, suggesting that the 
incentive structures that Goldhaber and Brewer identify notwithstanding, other factors may shape the development of distributed leadership literature.

Like many others, Goldhaber and Brewer are skeptical of the quality of educational research produced by professors working inside schools of education (for critiques of education schools from within, see Labaree, 2004; Lagemann, 2000; Levine, 2007). They advocated for "longerterm, more rigorously designed studies" (p. 209) but they also recognized that "studying schools and school districts requires access" (p. 209).

Cordial relationships must be established, nurtured, and preserved. Although this may not mean researchers pull punches with respect to their findings, it does suggest that there is an incentive to study issues that are not likely to embarrass the key constituencies and undermine the relations that will allow for future studies. (p. 209)

By drawing attention to the potential "to embarrass the key constituencies," Glodhaber and Brewer have made observations parallel to those of Datnow (2001), who suggested that conducting micropolitical research in schools has the potential to place participants at risk. Both observations would explain a general reluctance to examine micropolitics. Whether this disincentive also explains the disjuncture between distributed leadership and micropolitical research is not clear.

Micropolitics research and distributed leadership research are dissimilar in their popularity: Distributed leadership is much more likely to find its way into policy and professional literatures than writing on micropolitics. Louis (2005) provided one possible explanation for the different levels of popularity that these two fields have achieved with policymakers. In her analysis of the relationship between policy researchers and policymakers, she described the ways that both intentional and inadvertent politics of production affect what knowledge is taken up in policy discussions (p. 233). She also explained the power that issue networks have on the distribution of ideas. "It is the existence of overlapping networks that may account for the rapid diffusion of some research ideas. Other equally valid research may languish because it cannot find its way into a network" (p. 228). Thanks to the current policy emphasis on leadership, distributed leadership literature can be slotted quickly into several networks more seamlessly than can micropolitics research.

\section{CONCLUSION}

The divergence between distributed leadership and micropolitics research is noteworthy because the practice of school leadership, in both its formal and informal manifestations, includes administration, management, and micropolitics. Therefore, to neglect micropolitics is to neglect one of the themes that the field itself has identified as centrally significant. What does this divergence explain about the new politics of educational leadership?

The current educational policy environment can be characterized by two trends that often work in complementary ways. On one hand, policymakers have demonstrated an emphasis on centrally designed and coordinated mandates with explicit benchmarks set at the state or federal level (see Levin, 2008). On the other, both researchers and policymakers have paid increasing attention to "leadership" at the school level as the policy lever best positioned to remedy school underperformance; entrepreneurial, "no excuses" principals are central to this vision of leadership 
(see Carter, 1999; Leader, 2008; also see Copland, 2001, for a critique). In this era, school leaders' autonomy is potentially constrained to the observable implementation of mandated curricula or specific class sizes, or the achievement of certain success rates on exit exams or school scores awarded under inspection regimes, or the display of particular wall charts under a certain approach to literacy. Given this context, although principals' midlevel management activities are central to school-based change, it is not entirely a surprise that research on leadership at the school site would describe the ways conflicts could be eliminated or prevented from standing in the way of effective implementation. The split between the micropolitics and distributed leadership literatures is an artifact of the new politics of educational leadership. When policy directions for schools are set far away and further up the hierarchical chain of command, local micropolitics can be seen solely as managerial obstacles to be overcome.

Schools will not occupy this policy moment of centralized coordination forever and it will be important for our understanding both of leadership and of this historical moment to look back in a few years to see if distributed leadership is an expression of a particular kind of school administration with its roots in the accountability movement, or whether it has theoretical legs that will help understand leadership in more variable policy situations. Malen and Cochran (2008) similarly raised a call to pay attention to the ways that micropolitics are shaped in this particular policy moment.

To be sure, both longitudinal and comparative studies are required to gauge more precisely how actions taken at higher levels of the systems are permeating, if not dominating the micropolitics of schools. But the available research suggests that macro-forces may be controlling the agenda, limiting the latitude, restricting the scope of influence and otherwise circumscribing the power of site actors. If these findings hold, the macroforces in the policy environment may be among the most critical factors affecting the micropolitics in schools. (p. 168)

The problem with ignoring micropolitics in the study of school leadership is that the vision of schooling that is left behind is one that is not only overly simplified, but it also reinforces an idea that conflict within schools is a pathology best avoided. For those who consider schools essentially neutral or positive places where micropolitics distracts from schools' more important functions, this stance makes sense. But for those who see schools as always shaped by conflict over goals and purposes, attending to micropolitics means that important concerns about school unfairness or inequity, ignored in the standard operating procedures from day to day, might come to light (see, e.g., Singleton \& Linton, 2005). According to this second perspective, the skill school leaders need is not the perfect strategy to engage in the impossible struggle to eliminate micropolitics but instead the skill of inquiry to look for it in every instance, to examine who gains and who loses under important school decisions, and to develop a better understanding of the concerns that motivate people to join together in support or opposition of school initiatives. Practicing a skill of inquiry means neither relinquishing overarching commitments nor bending to whichever group's voice is strongest. Instead, it means viewing politics as inevitable and using the always-latent conflicts as generative of information about what matters most to school stakeholders.

Not all conflict is productive, and neither will attending to all micropolitical dynamics within a school lead to positive results. As Marshall and Scribner (1991) explained, 
On one hand, micropolitical analysis can provide eminently practical insights for practitioners. Educators can use micropolitical skills to plan alterations in resources and manipulation of symbols to reduce inequities and to increase the power and voice of previously powerless groups.... However, these same skills could be used as easily to advance less socially desirable political agendas. (p. 352)

Acknowledging political dynamics and pursuing them intentionally requires articulating the values that drive and organize leadership decisions. It may be exactly this fact that most stands in the way of a merging of distributed leadership and micropolitical analyses, for the distributed leadership literature, like much of the leadership literature in general, is far more likely to take up technical issues of school organization than it is to examine what significance or relevance those issues have (see Noguera, 2006). Micropolitical conflicts provide information. Sometimes the information tells us that people are shortsighted or selfish or irrationally stubborn. But sometimes the information shows us what adults in schools value in their professional practice and what families aspire to for their children. Understanding those values and attempting to serve them are leadership responsibilities, and research that seeks to inform leadership practice should examine them.

\section{REFERENCES}

Achinstein, B. (2002). Community, diversity, and conflict among schoolteachers: The ties that blind. New York: Teachers College Press.

Anderson, S., \& Rodway, J. (2008, May). Superintendent perspectives on student learning in an era of standards and accountability: A collective frame analysis. Paper presented at the annual conference of the Canadian Society for Studies in Education, Vancouver, Canada.

Bennett, N., Wise, C., Woods, P., \& Harvey, J. (2003). Distributed leadership, summary report. Nottingham, UK: National College for School Leadership. Available from http://www.ncsl.org.uk/literaturereviews

Blase, J. (1995). The micro-politics of education. In R. Donmoyer, M. Imber, \& J. J. Scheurich (Eds.), The knowledge base in educational administration: Multiple perspectives (pp. 209-224). Albany: The State University of New York Press.

Blase, J., \& Blase, J. (1997). The micro-political orientation of facilitative school principals and its effects on teachers' sense of empowerment. Journal of Educational Administration, 35(2), 138-164.

Bolman, L., \& Deal, T. (2004). Reframing organizations: Artistry, choice, and leadership, third edition. San Francisco: Jossey-Bass.

Bryk, A., Sebring, P., Kerbow, D., Rollow, S., \& Easton, J. (1998). Charting Chicago school reform: democratic localism as a lever for change. Boulder, $\mathrm{CO}$ : Westview.

Camburn, E., Rowan, B., \& Taylor, J. (2003). Distributed leadership in schools: The case of elementary schools adopting comprehensive school reform models. Educational Evaluation and Policy Analysis, 25(4), 347-373.

Carter, S. (1999). No excuses: Seven principals of low-income schools who set the standard for high achievement. Washington, DC: Heritage Foundation.

Coburn, C. (2006). Framing the problem of reading instruction: Using frame analysis to uncover the micro-processes of policy implementation. American Educational Research Journal, 43(3), 343-379.

Copland, M. (2001). The myth of the superprincipal. Phi Delta Kappan, 82, 528-533.

Creed, W. E. D., Langstraat, J., \& Scully, M. (2002). A picture of the frame: Frame analysis as technique and as politics. Organizational Research Methods, 5(1), 34-55.

Cuban, L. (1988). The managerial imperative and the practice of leadership in schools. Albany: State University of New York Press.

Cuban, L. (2001). How can I fix it?: Finding solutions and managing dilemmas: An educator's road map. New York: Teachers College Press. 
Datnow, A. (2001). Gender politics in school reform. In N. Bascia \& A. Hargreaves (Eds.), The sharp edge of educational change: Teaching, leading, and the realities of reform (pp. 131-154). London: Routledge Falmer.

Goldhaber, D., \& Brewer, D. (2008). What gets studied and why: Examining the incentives that drive education research. In F. Hess (Ed.), When research matters: How scholarship influences education policy (pp. 197-217). Cambridge, MA: Harvard Education Press.

Gronn, P. (2000). Distributed properties: A new architecture for leadership. Educational Management, Administration \& Leadership, 28, 317-338.

Gronn, P. (2002). Distributed leadership as a unit of analysis. The Leadership Quarterly, 13, 423-451.

Grubb, W. N., \& Flessa, J. (2006). "A job too big for one": Multiple principals and other nontraditional approaches to school leadership. Educational Administration Quarterly, 42(4), 518-550.

Haggerty, K. (2004). Ethics creep: Governing social science research in the name of ethics. Qualitative Sociology, 27, 391-414.

Hallett, T. (2007). The leadership struggle: The case of Costen Elementary School. In J. Spillane, \& J. Diamond (Eds.), Distributed leadership in practice (pp. 85-105). New York: Teachers College Press.

Halverson, R. (2007). Systems of practice and professional community: The Adams case. In J. Spillane \& J. Diamond (Eds.), Distributed leadership in practice (pp. 35-59). New York: Teachers College Press.

Hartley, D. (2007). The emergence of distributed leadership in education: Why now? British Journal of Educational Studies, 55(2), 202-214.

Hatcher, R. (2005). The distribution of leadership and power in schools. British Journal of Sociology of Education, 26(2), 253-267.

Heck, R., \& Hallinger, P. (2005). The study of educational leadership and management: Where does the field stand today? Educational Management, Administration, and Leadership, 33(2), 229-244.

Heller, M., \& Firestone, W. (1995). Who's in charge here? Sources of leadership for change in eight schools. The Elementary School Journal, 96(1), 65-86.

Hoyle, E. (1982). Micro-politics of educational organizations. Educational Management and Administration, 10, 87-98.

Iannaccone, L. (1991). Micro-politics of education: What and why. Education and urban society, 23(4), 465-471.

Johnson, B. (2004). Local school micro-political agency: An antidote to new managerialism. School leadership and management, 24(3), 267-286.

Labaree, D. (2004). The trouble with ed schools. New Haven, CT: Yale University Press.

Lagemann, E.C. (2000). An elusive science: The troubling history of educational research. Chicago: University of Chicago Press.

Lakoff, G. (2004). Don't think of an elephant! Know your values and frame the debate: the essential guide for progressives. White River Junction, VT: Chelsea Green.

Lakoff, G. (2006). Simple framing: An introduction to framing and its uses in politics. Rockridge Institute. Available from http://www.rockridgeinstitute.org/projects/strategic/simple_framing/

Leader, G., with Stern, A. (2008). Real leaders, real schools: Stories of success against enormous odds. Cambridge, MA: Harvard Education Press.

Lee, V., \& Smith, J. (2001). The organization of teachers' work lives. In V. Lee, with J. Smith, (Eds.), Restructuring high schools for equity and excellence (pp. 81-101). New York: Teachers College Press.

Leithwood, K., Mascall, B., \& Strauss, T. (Eds.). (2009). Distributed leadership according to the evidence. New York: Routledge.

Levin, B. (2008). How to change 5000 schools: A practical and positive approach for leading change at every level. Cambridge, MA: Harvard Education Press.

Levine, A. (2007). Educating researchers. New York: Education Schools Project.

Louis, K. S. (2005). Knowledge producers and policymakers: Kissing kin or squabbling siblings? In N. Bascia, A. Cumming, A. Datnow, K. Leithwood, \& D. Livingstone (Eds.), International handbook of educational policy (pp. 219-238). Dordrect, the Netherlands: Springer.

Malen, B. (1995). The micro-politics of education: Mapping the multiple dimensions of power relations in school politics. In J. D. Scribner \& D. H. Layton (Eds.), The study of educational politics (pp. 147-167). Washington, DC: Falmer.

Malen, B., \& Cochran, M. V. (2008). Beyond pluralistic patterns of power: Research on the mircopolitics of schools. In B. Cooper, J. Cibulka, \& L. Fusarelli (Eds.), Handbook of education politics and policy (pp. 148-178). New York: Routledge.

Marshall, C., \& Scribner, J. (1991). "It's all political": Inquiry into the micro-politics of education. Education and Urban Society, 23(4), 347-355. 
Mawhinney, H. (1999). Reappraisal: the problems and prospects of studying the micro-politics of leadership in reforming schools. School Leadership and Management, 19(2), 159-170.

Maxcy, B., \& Nguyen, T. S. T. (2006). The politics of distributing leadership: Reconsidering distribution in two Texas elementary schools. Educational Policy, 20(1), 163-196.

Mayrowetz, D. (2008). Making sense of distributed leadership: Exploring the multiple usages of the concept in the field. Educational Administration Quarterly, 44(3), 424-435.

McBeth, M. (2008). The distributed leadership toolbox: Essential practices for successful schools. Thousand Oaks, CA: Corwin.

McKenzie, K. B., \& Scheurich, J. J. (2004). Equity traps: A useful construct for preparing principals to lead schools that are successful with racially diverse students. Educational Administration Quarterly, 40(5), 601-632.

Noguera, P. (2006). A critical response to Michael Fullan's "The Future of Educational Change: System Thinkers in Action." Journal of Educational Change, 7, 129-132.

Ogawa, R. (2005). Leadership as a social construct: The expression of human agency within organizational constraint. In F. English (Ed.), The Sage handbook of educational leadership: Advances in theory, research, and practice (pp. 89-108). Thousand Oaks, CA: Sage.

Ogawa, R., \& Bossert, S. (1995). Leadership as an organizational quality. Educational Administration Quarterly, 31(2), 224-243.

Scott, W. R. (1987). Organizations: Rational, natural, and open systems. Englewood Cliffs, NJ: Prentice Hall.

Shipps, D., \& White, M. (2009/this issue). A new politics of the principalship? Accountability-driven change in New York City. Peabody Journal of Education, 84, 350-373.

Singleton, G., \& Linton, C. (2005). Courageous conversations about race: A field guide for achieving equity in schools. Thousand Oaks, CA: Corwin.

Spillane, J. (2006). Distributed leadership. San Francisco: Jossey-Bass.

Spillane, J., Camburn, E., \& Pareja, A. (2007). Taking a distributed perspective to the school principal's workday. Leadership and Policy in Schools, 6, 103-125.

Spillane, J., \& Diamond, J. (Eds.). (2007). Distributed leadership in practice. New York: Teachers College Press.

Stone, D. (2002). Policy paradox: The art of political decision making. Revised edition. New York: Norton.

Storey, A. (2004). The problem of distributed leadership in schools. School leadership and management, 24(3), $249-265$.

Timperley, H. (2005). Distributed leadership: Developing theory from practice. Journal of Curriculum Studies, 37(4), $395-420$.

Tyack, D., \& Cuban, L. (1995). Tinkering toward utopia: A century of public school reform. Cambridge, MA: Harvard University Press.

Tyack, D., \& Hansot, E. (1982). Managers of virtue: Public school leadership in America, 1820-1980. New York: Basic Books.

van den Hoonaard, W. (2003). Is anonymity an artifact in ethnographic research? Journal of Academic Ethics, 1, 141-151.

West, M. (1999). Micro-politics, leadership, and all that ... The need to increase micro-political awareness and skills of school leaders. School Leadership and Management, 19(2), 189-195. 
Copyright of PJE. Peabody Journal of Education is the property of Lawrence Erlbaum Associates and its content may not be copied or emailed to multiple sites or posted to a listserv without the copyright holder's express written permission. However, users may print, download, or email articles for individual use. 